\title{
PENGARUH KONSELING TERHADAP TINGKAT KECEMASAN IBU PRIMIGRAVIDA DALAM MENGHADAPI PERSALINAN DI BPM Hj. SRI LUMINTU
}

\section{Effect of Counseling on Primigravida Mothers' Anxiety Level in Delivery at Hj. Sri Lumintu Independent Midwifery Practice}

\author{
Latifah Nur Rahmadani 1), Sri Anggarini ${ }^{2)}$, Sri Mulyani ${ }^{3)}$ \\ 1) Pasca Sarjana Ilmu Kesehatan Masyarakat, Universitas Sebelas Maret, Jl. Ir. Sutami 36A, \\ Kentingan, Surakarta 57126 telp. (0271) 662622, Indonesia \\ ${ }^{2,3)}$ Prodi D IV Bidan Pendidik, Fakultas Kedokteran, Universitas Ssebelas Maret, Jl. Ir. Sutami \\ 36A, Kentingan, Surakarta 57126 telp. (0271) 662622, Indonesia
}

e-mail: latifahnr8@gmail.com

\begin{abstract}
ABSTRAK
Latar Belakang: Perubahan ibu hamil tidak hanya perubahan fisik, tetapi juga psikososial, salah satunyakecemasan dan apabila tidak ditangani dengan baik dapat memberikan dampak buruk baik bagi ibu maupun janin. Konseling merupakan salah satu cara menurunkan tingkat kecemasan ibu hamil trimester III dalam menghadapi persalinan. Penelitian ini bertujuan mengetahui pengaruh konseling terhadap tingkat kecemasan ibu primigravida dalam menghadapi persalinan di BPM Hj. Sri Lumintu.

Metode: Jenis penelitian quasy experimen dengan pendekatannon randomized control group pretest posttest design. Penelitian ini dilakukan di BPM Hj. Sri Lumintu. Sampel sejumlah34 ibu primigravidatrimester III, yaitu 17 ibu kelompok kontrol dan $17 \mathrm{ibu}$ kelompok eksperimen dengan teknik purposive sampling. Instrumen penelitian menggunakan kuesioner $H R S$-Ayang telah dimodifikasi. Teknik analisis data menggunakan Wilcoxon dan Chi Square dengan program SPSS 16.0.

Hasil: Hasil uji Wilcoxon tingkat kecemasan kelompok kontrol pada saat pretest maupun posttest diperoleh nilai signifikansi 1,000sedangkan pada tingkat kecemasankelompok eksperimen nilai signifikansi sebelum dan sesudah diberi konseling 0,000. Berdasarkan uji Chi Square, nilai signifikansi kelompok kontrol dan eksperimen sesudah intervensi adalah 0,037 .

Simpulan: Terdapat pengaruh konseling terhadap tingkat kecemasan ibu primigravida dalam menghadapi persalinan di BPM Hj. Sri Lumintu Tahun 2016.
\end{abstract}

Kata kunci: Konseling, Kecemasan, Ibu Primigravida Trimester III 


\begin{abstract}
Background: During pregnancy, the gestational mothers experience not only physical but also psychosocial changes. One of which is their anxiety level. If not treated properly, it will give bad impacts to the mothers and their fetuses.Counseling is one of ways to lower the anxiety level of the gestational mothers in Trimester III when undergoing the delivery. The objective of this research is to investigate the effect of counseling on the primigravida mothers' anxiety level in undergoing the delivery at Hj. Sri Lumintu Independent Midwifery Practice.

Method: This research used the quasi experimental research method with the non randomized control group pretest posttest design. It was conducted at Hj. Sri Lumintu Independent Midwifery Practice. The samples of research consisted of 34 primigravidamothers in Trimester III, 17 mothers control group and 17 mothers experiment group by using the purposive sampling technique. The data of research were collected through the modified questionnaire of HARS analyzed by using the the Wilcoxon's test and Chi Square's test aided with the computer program of SPSS 16.0.

Result: The result of the Wilcoxon's test shows that the significance value of the anxiety level of the control group in the pre-test and in the post-test was 1.000, and that of the experimental group prior to and following the counseling was 0.000. The result of the Chi Square's test shows that the significance value of the anxiety level of both the control group and the experimental group following the intervention was 0.037.

Conclusion: The counseling had an effect on the primigravida mothers' anxiety level in undergoing the delivery at Hj. Sri Lumintu Independent Midwifery Practice in 2016.
\end{abstract}

\title{
Keywords: Counseling, anxiety level, Primigravida mothers in Trimester III
}

\section{PENDAHULUAN}

Persalinan dan kelahiran merupakan kejadian fisiologis dalam kehidupan. Menurut Reva Rubin selama hamil perubahan-perubahan tidak semata terjadi pada perubahan fisik, tetapi juga terjadi perubahan psikososial seperti rasa tidak nyaman, rasa kecewa, sikap penolakan, cemas dan sedih [1].

Kecemasan merupakan bagian dari respon emosional terhadap penilaian individu yang subjektif yang keadaannya dipengaruhi alam bawah sadar. Selama periode kehamilan hampir sebagian besar ibu hamil sering mengalami kecemasan. Setiap ibu hamil memiliki tingkat kecemasan yang berbeda dan tergantung pada sejauh mana ibu mempersepsikan kehamilannya [2].

Kecemasan, ketakutan dan panik berdampak negatif pada ibu sejak masa kehamilan sampai persalinan. Kecemasan dan ketakutan akan menimbulkan stress.
Stres yang terus menerus selama kehamilan akan mempengaruhi perkembangan fisiologis dan psikologis janin. Stres ekstrem dapat menyebabkan kelahiran premature, BBLR, hiperaktif, dan mudah $\operatorname{marah}^{[1]}$.

Cara yang dapat dilakukan untuk mengatasi kecemasan ibu dalam menghadapi persalinan adalah melalui konseling. Informasi yang diberikan diharapakan dapat mengurangi pengaruh negatif berupa kecemasan dan ketakutan akibat pengaruh cerita-cerita yang menakutkan mengenai kehamilan dan persalinan. Selain itu, konseling dapat memperkuat pengaruh positif dengan memberikan dukungan mental dan penjelasan tentang kebahagiaan akan mempunyai anak yang diinginkan ${ }^{[2]}$.

Berdasarkan latar belakang diatas peneliti tertarik melakukan penelitian ini. Tujuan dari penelitian ini adalah untuk mengetahui pengaruh konseling terhadap tingkat kecemasan ibu primigravida 
menghadapi persalinan di BPM $\mathrm{Hj}$. Sri Lumintu Tahun 2016.

\section{SUBJEK DAN METODE \\ Jenis penelitian ini adalah quasi experi- men dengan pendekatannon randomized control group pretest posttest design. Penelitian ini dilaksanakan di BPM Hj. Sri Lumintu Kota Surakarta.}

Populasi dalam penelitian ini adalah semua ibu hamil trimester tiga yang memeriksakan kehamilan di BPM $\mathrm{Hj}$. Sri Lumintu.

Tenik pengambilan sampel menggunakan purposive sampling dengan kriteria inklusi dan eksklusi ${ }^{3}$. Besar sampel dihitung dengan menggunakan rumus besar sampel minimal:

$$
n_{1}=n_{2}=2\left[\frac{\left(z_{\alpha}+z_{\beta}\right) s}{\left(X_{1}-X_{2}\right)}\right]^{2}
$$

Perhitungan besar sampel menggunakan Power and Sample Size Program didapatkan hasil 15 ibu dengan nilai drop out sebesar $10 \%$ sehingga besar sampel untuk setiap kelompok adalah 17 ibu. Jumlah sampel keseluruhan sebanyak 34 ibu.

Instrumen penelitian yaitu kuesioner HARS yang telah dimodifikasi. Analisis data menggunakan Wilcoxon dan ChiSquare dengan program SPSS 16.0.

1. Analisis Univariat

Tabel 1. Distribusi Frekuensi Responden Berdasarkan Usia

\begin{tabular}{ccccc}
\hline \multirow{2}{*}{ Usia } & \multicolumn{4}{c}{ Kelompok } \\
\cline { 2 - 5 } & \multicolumn{2}{c}{ Eksperimen } & \multicolumn{2}{c}{ Kontrol } \\
& $\mathrm{N}$ & $\%$ & $\mathrm{~N}$ & $\%$ \\
\hline 20-25 tahun & 12 & 70,6 & 8 & 47.06 \\
26-30 tahun & 4 & 23,52 & 9 & 52,94 \\
31-35 tahun & 1 & 5,88 & 0 & 0 \\
Jumlah & $\mathbf{1 7}$ & $\mathbf{1 0 0}$ & $\mathbf{1 7}$ & $\mathbf{1 0 0}$ \\
\hline
\end{tabular}

Pada tabel 1 dapat diketahui usia responden kelompok eksperimen paling banyak berusia 20-25 tahun yaitsu sebesar 70,6\% . Pada kelompok kontrol diketahui bahwa responden terbanyak berusia 26-30 tahun yaitu sebesar 52,94\%.
Tabel 2. Distribusi Frekuensi Responden Berdasarkan Tingkat Pendidikan

\begin{tabular}{ccccc}
\hline \multirow{2}{*}{ Tingkat } & \multicolumn{3}{c}{ Kelompok } \\
\cline { 2 - 5 } Pendidikan & \multicolumn{2}{c}{ Eksperimen } & \multicolumn{2}{c}{ Kontrol } \\
& $\mathrm{N}$ & $\%$ & $\mathrm{n}$ & $\%$ \\
\hline SMA & 16 & 94,12 & 9 & 52,94 \\
Diploma & 0 & 0 & 3 & 17,65 \\
S1 & 1 & 5,88 & 5 & 29,41 \\
Jumlah & $\mathbf{1 7}$ & $\mathbf{1 0 0}$ & $\mathbf{1 7}$ & $\mathbf{1 0 0}$ \\
\hline
\end{tabular}

Interpretasi data pada tabel 2 dapat disimpulkan bahwa tingkat pendidikan pada kelompok eskperimen paling banyak ialah SMA sebesar $94,12 \%$ dan pada kelompok kontrol 52,94\%.

Tabel 3. Distribusi Frekuensi Responden Berdasarkan Pekerjaan

\begin{tabular}{ccccc}
\hline \multirow{2}{*}{ Pekerjaan } & \multicolumn{4}{c}{ Kelompok } \\
\cline { 2 - 5 } & \multicolumn{2}{c}{ Eksperimen } & \multicolumn{2}{c}{ Kontrol } \\
& $\mathrm{N}$ & $\%$ & $\mathrm{~N}$ & $\%$ \\
\hline Tidak & 9 & 52,94 & 7 & 41,18 \\
bekerja & & 47,06 & 10 & 58,82 \\
Bekerja & 8 & 47,06 & $\mathbf{1 7}$ & $\mathbf{1 0 0}$ \\
Jumlah & $\mathbf{1 7}$ & $\mathbf{1 0 0}$ & $\mathbf{1 0}$
\end{tabular}

Tabel 3 menunjukkan bahwa pekerjaan ibu pada kelompok eksperimen mayoritas tidak bekerja, sedangkan pada kelompok kontrol mayoritas ibu bekerja.

Tabel 4. Distribusi Tingkat Kecemasan Responden Sebelum Diberi Konseling pada Kelompok Eksperimen dan Kontrol

\begin{tabular}{lcc}
\hline Tingkat Kecemasan & N & \% \\
\hline Kelompok & & \\
Eksperimen & 0 & 0 \\
Tidak Cemas & 7 & 41,18 \\
Cemas Ringan & 10 & 58,82 \\
Cemas Sedang & 0 & 0 \\
Cemas Berat & 17 & 100 \\
Jumlah & & \\
Kelompok Kontrol & 0 & 0 \\
Tidak Cemas & 9 & 52,94 \\
Cemas Ringan & 8 & 47,06 \\
Cemas Sedang & 0 & 0 \\
Cemas Berat & 17 & 100 \\
Jumlah &
\end{tabular}

Tabel 4 menunjukkan pada kelompok eksperimen sebelum diberi konseling paling banyak pada kecemasan sedang yaitu sebesar $58,82 \%$, sedangkan pada kelompok 
kontrol paling banyak pada kecemasan ringan yaitu sebesar 52,94\%.

Tabel 5. Distribusi Tingkat Kecemasan Responden Setelah Diberi Konseling pada Kelompok Eksperimen dan Kontrol

\begin{tabular}{lcc}
\hline Tingkat Kecemasan & n & \% \\
\hline Kelompok Eksperimen & & \\
Tidak Cemas & 6 & 35,30 \\
Cemas Ringan & 11 & 64,70 \\
Cemas Sedang & 0 & 0 \\
Cemas Berat & 0 & 0 \\
Jumlah & 17 & 100 \\
Kelompok Kontrol & & \\
Tidak Cemas & 0 & 0 \\
Cemas Ringan & 9 & 52,94 \\
Cemas Sedang & 8 & 47,06 \\
Cemas Berat & 0 & 0 \\
Jumlah & 17 & 100 \\
\hline
\end{tabular}

Tabel 5 menunjukkan bahwa posttest pada kelompok eksperimen setelah diberi konseling paling banyak pada kecemasan ringan yaitu sebesar $64,70 \%$, sedangkan responden yang tidak mengalami kecemasan sebesar 35,30\%. Pada kelompok kontrol hasil posttest menunjukkan responden yang mengalami kecemasan ringan sebesar 52,94\% dan yang mengalami kecemasan sedang sebesar $47,06 \%$.

\section{Analisis Bivariat}

Tabel 6. Uji Analisis Tingkat Kecemasan Primigravida Sebelum (Pretest) dan Sesudah (Posttest) pada Kelompok
Kontrol

\begin{tabular}{|c|c|c|c|}
\hline \multirow{2}{*}{ Kecemasan } & \multicolumn{2}{|c|}{ Hasil } & \multirow{2}{*}{$\begin{array}{c}P- \\
\text { value }\end{array}$} \\
\hline & Pre & Post & \\
\hline Tidak Cemas & 0 & 0 & 1,000 \\
\hline Cemas Ringan & 9 & 9 & \\
\hline Cemas Sedang & 8 & 8 & \\
\hline Cemas Berat & 0 & 0 & \\
\hline Jumlah & 17 & 17 & \\
\hline
\end{tabular}

Berdasarkan hasil uji Wilcoxon diperoleh nilai $p$-value 1,000 . Interpretasi nilai $\mathrm{p}>$ 0,05, maka dapat disimpulkan bahwa tidak ada perbedaan kecemasan secara signifikan antara sebelum (Pretest) dan sesudah (Posttest) pada kelompok kontrol.

Tabel 7. Uji Analisis Tingkat Kecemasan Primigravida Sebelum (Pretest) dan Sesudah (Posttest) pada Kelompok Eksperimen

\begin{tabular}{lccl}
\hline \multirow{2}{*}{ Kecemasan } & \multicolumn{2}{c}{ Hasil } & P-value \\
\cline { 2 - 3 } & Pre & Post & \\
\hline Tidak Cemas & 0 & 6 & 0,000 \\
Cemas Ringan & 7 & 11 & \\
Cemas Sedang & 10 & 0 & \\
Cemas Berat & 0 & 0 & \\
\hline Jumlah & $\mathbf{1 7}$ & $\mathbf{1 7}$ & \\
\hline
\end{tabular}

Berdasarkan hasil uji Wilcoxon diperoleh nilai $p$-value 0,000 . Interpretasi nilai $\mathrm{p}<$ 0,05 , maka dapat disimpulkan bahwa ada perbedaan kecemasan secara signifikan sebelum (pretest) dan sesudah (posttest) pada kelompok eksperimen.

Tabel 8. Perbedaan Tingkat Kecemasan Primigravida Sesudah (Posttest) pada Kelompok Eksperimen dan Kelompok Kontrol

\begin{tabular}{|c|c|c|c|c|c|}
\hline \multirow[b]{2}{*}{ 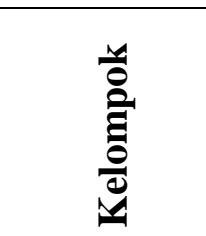 } & \multicolumn{3}{|c|}{ R 0 an $w$ wo on } & \multirow{2}{*}{ 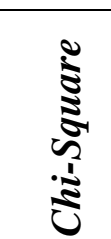 } & \multirow[b]{2}{*}{$\frac{2}{3}$} \\
\hline & Uี & שี & Uี & & \\
\hline Eksperimen & 6 & 11 & 0 & 6,588 & 0,037 \\
\hline Kontrol & 0 & 9 & 8 & & \\
\hline
\end{tabular}

Berdasarkan hasil uji Chi-Square diperoleh nilai $p$-value 0,037 . Interpretasi nilai $\mathrm{p}<0,05$, maka dapat disimpulkan bahwa terdapat perbedaan kecemasan setelah konseling secara signifikan antara kelompok eksperimen dan kelompok kontrol.

\begin{tabular}{l}
\hline PEMBAHASAN \\
\hline Karakteristik Responden \\
Mempengaruhi Kecemasan \\
Hasil penelitian menunjukkan bahwa ma- \\
yoritas responden berada pada usia $20-25$ \\
tahun yaitu sebanyak 20 responden. Dari
\end{tabular}


20 responden tersebut sebagian besar mengalami kecemasan sedang. Kecemasan sedang memungkinkan orang untuk memusatkan pada hal yang penting dan mengesampingkan hal lain, sehingga seseorang mengalami tidak perhatian yang selektif namun dapat melakukan sesuatu yang lebih banyak jika diberi arahan ${ }^{[4]}$.

Usia merupakan salah satu faktor yang mempengaruhi tingkat kecemasan seseorang. Usia yang lebih muda lebih mudah menderita stress dari pada usia tua. Semakin tinggi usia semakin baik tingkat kematangan emosi seseorang serta kemampuan dalam menghadapi berbagai persoalan ${ }^{[5]}$.

Tingkat pendidikan sebagian besar responden dalam penelitian ini adalah SMA yaitu sebesar $73,53 \%$ (25 orang). Orang yang mempunyai pendidikan lebih tinggi akan memberikan respon yang lebih rasional dibandingkan mereka yang tidak berpendidikan tidak mampu menghadapi suatu tantangan dengan rasional ${ }^{[6]}$.

Tingkat pendidikan juga merupakan salah satu faktor yang mempengaruhi persepsi seseorang untuk lebih mudah menerima ide teknologi baru, dimana semakin tinggi pendidikan seseorang semakin besar peluang untuk mencari pengobatan ke pelayanan kesehatan ${ }^{[7]}$.

Karakteristik pekerjaan sebagian besar responden adalah bekerja yaitu sebesar $52,95 \%$ (18 orang). Pekerjaan ibu hamil tidak hanya menunjukkan tingkat sosial ekonomi,melainkan juga menunjukkan ada tidaknya interaksi ibu hamil dalam masyarakat yang luas dan keaktifan pada organisasi tertentu, dengan asumsi ibu yang bekerja akan memiliki pengetahuan yang lebih tinggi dan menerima informasi lebih cepat daripada ibu yang tidak bekerja.

\section{Tingkat Kecemasan Primigravida Menghadapi Persalinan}

Tingkat kecemasan sebelum (pretest) sebagian responden pada kelompok kontrol adalah kecemasan ringan yaitu sebesar $52,94 \%$ (9 orang), sedangkan responden yang mengalami kecemasan sedang sebe- sar $47,06 \%$ (8 orang). Setelah diberikan posttest kecemasan ibu pada kelompok kontrol tidak mengalami perubahan karena pada kelompok kontrol tidak diberikan perlakuan konseling.

Pada kelompok eksperimen, hasil penelitian menunjukkan bahwa ibu yang mengalami kecemasan sedang sebesar 58,82 (10 orang), sedangkan ibu yang mengalami kecemasan ringan sebesar $41,18 \%$ (7 orang). Setelah diberikan perlakuan berupa konseling kecemasan ibu menurun menjadi kecemasan ringan sebesar $64,70 \%$ (11 orang) dan ibu yang tidak cemas sebesar $35,30 \%$ (6 orang).

Pada kelompok kontrol sebagian besar ibu berusia 26-30 tahun (9 orang), sedangkan pada kelompok eksperimen sebagian besar ibu berusia 20-25 tahun (12 orang). Usia merupakan salah satu karakteristik yang dapat mempengaruhi kecemasan ibu primigravida dalam menghadapi persalinan ${ }^{[4]}$.

Hasil penelitian berdasarkan tingkat pendidikan menunjukkan bahwa pada kelompok kontrol ibu yang berpendidikan SMA sebesar 52,94 (9 orang), diploma sebesar 17,65\% (3 orang) dan S1 sebesar $29,41 \%$ (6 orang), sedangkan pada kelompok eksperimen tingkat pendidikan ibu mayoritas adalah SMA yaitu sebesar $94,12 \%$ (16 orang).

Tingkat pendidikan juga dapat mempengaruhi tingkat kecemasan seseorang. Tingkat pendidikan seseorang berpengaruh dalam memberikan respon terhadap sesuatu dan kemampuan berfikir. Semakin tinggi tingkat pendidikan akan semakin mudah berfikir rasional dan menangkap informasi baru termasuk dalam menguraikan masalah yang baru ${ }^{[3]}$.

Kepercayaan yang dimiliki ibu primigravida dalam mempercayai hal-hal yang berkaitan dengan persalinan baik itu dari mitos daerah setempat ataupun cerita dari pengalaman orang lain tentang persalinan juga dapat mempengaruhi tingkat kecemasan ibu dalam menghadapi persalinan.

Ibu hamil tidak jarang memiliki pi- 
kiran yang mengganggu, sebagai pengembangan reaksi kecemasan terhadap cerita yang diperolehnya. Semua orang selalu mengatakan bahwa melahirkan itu sakit sekali.Oleh karena itu muncul ketakutanketakutan pada ibu hamil ${ }^{[8]}$.

\section{Pengaruh Konseling terhadap Tingkat Kecemasan Primigravida Menghadapi Persalinan}

Berdasarkan hasil uji Chi-Square diperoleh nilai $p$-value 0,037 . Interpretasi nilai $\mathrm{p}<0,05$, maka dapat disimpulkan bahwa terdapat perbedaan kecemasan setelah konseling secara signifikan antara kelompok eksperimen dan kelompok kontrol.

Kecemasan pada ibu hamil dialami karena persepsi ibu yang kurang tepat mengenai proses persalinan. Persalinan dipersepsikan sebagai proses yang menakutkan dan menimbulkan rasa sakit yang luar biasa. Nyeri selama persalinan juga merupakan salah satu faktor yang ditakuti oleh ibu ibu hamil sehingga menyebabkan kecemasan saat menjelang persalinan ${ }^{[9]}$.

Penurunan kecemasan primigravida setelah mengikuti konseling terjadi karena saat konseling primigravida telah mampu mengungkapkan semua perasaan yang menggangu dan merasa lega serta menciptakan kondisi relaks pada primigravida. Diharapkan dengan kondisi relaks baik pada tubuh dan pikiran dapat memicu pelepasan hormon yang akan membantu menurunkan kecemasan.

Ibu hamil yang mengalami kecemasan dan stres, secara tidak langsung otak akan bekerja dan mengeluarkan corticotrophin-releasing hormone (CHR). CHR merupakan master hormon stres yang akan memicu pelepasan hormon stress $g l u$ kokortikoid. Dengan dirangsang oleh glukokortikoid dan hormon stres lainnya, seperti adrenalin, maka otak dan tubuh akan mengalami ketegangan dan krisis.

Ketika tercapainya kondisi relaksasi, maka primigravida dapat mengakses sifat primitif pada otak belakangnya sehingga memicu pengeluran hormon endorfin. Karena endorfin adalah hormon alami yang diproduksi oleh tubuh manusia, maka endorfin adalah penghilang rasa sakit yang terbaik, selain itu juga bermanfaat untuk mengurangi stress, meningkatkan sistem kekebalan tubuh, dan memperlambat proses penuaan. Hal tersebut menunjukkan bahwa faktor psikologis sangat berkaitan dan menentukan reaksi fisiologis kehamilan dan persalinan. Ketenangan yang didapatkan setelah mengikuti proses konseling memberikan ketenangan dan kesiapan secara psikologis pada primigravida sehingga akan membantu memperlancar proses persalinan.

Perubahan yang ditunjukkan dengan penurunan kategori kecemasan pada kelompok eksperimen menunjukkan bahwa konseling memberikan pengaruh positif bagi primigravida yang mengikuti, sehingga kecemasan yang dialami dalam menghadapi proses persalinan dapat menurun ${ }^{[10]}$.

Penelitian yang memperkuat hasil penelitian ini adalah penelitian Pengaruh Konseling Terhadap Kecemasan Ibu Menjelang Persalinan di Rumah Sakit Umum Daerah Labuang Baji Makassar, dengan hasil ada pengaruh konseling terhadap penurunan kecemasan ibu menjelang persalinan dengan nilai $p$-value $0,000^{[11]}$.

\section{SIMPULAN DAN SARAN}

\section{Simpulan}

a. Tidak ada perbedaan kecemasan ibu sebelum konseling antara kelompok eksperimen dengan kelompok kontrol.

b. Ada perbedaan kecemasan ibu sebelum dengan sesudah diberi konseling pada kelompok eksperimendan tidak ada perbedaan kecemasan ibu sebelum dengan sesudah konseling pada kelompok kontrol.

c. Ada pengaruh konseling terhadap tingkat kecemasan ibu primigravida menghadapi persalinan di BPM $\mathrm{Hj}$. Sri Lumintu dengan nilai p-value 0,037 .

\section{Saran}

\section{Bagi BPM Hj. Sri Lumintu}

Informasi yang diberikan tentang persalinan sebaiknya dilakukan dengan konseling minimal satu kali pada trimester III 
sebagai upaya untuk mengatasi dan mencegah kecemasan pada ibu primigravida dalam menghadapi persalinan.

\section{Bagi Ibu Hamil}

Ibu hamil diharapkan ikut berpartisipasi secara aktif dan dapat menjadikan konseling sebagai sarana untuk mempersiapkan diri dalam menjalani proses persalinan-

\section{DAFTAR PUSTAKA}

1. Pieter, H. Z., Lubis, N. L. (2010). Pengantar Psikologi untuk Kebidanan. Jakarta: Kencana Prenada Media Group

2. Janiwarty, B., Pieter, H. Z. (2013). Pendidikan Psikologi untuk Bidan. Yogyakarta: ANDI

3. Sastroasmoro, S. (2011). DasarDasar Metodologi Penelitian Klinis. Jakarta: Sagung Seto

4. Stuart, G. W., Sundeen, S. J. (2006). Buku Saku Keperawatan Jiwa. Jakarta: EGC

5. Lestari, T. (2014).Kumpulan Teori untuk Kajian Pustaka Penelitian Kesehatan. Yogyakarta: Nuha Medika

6. Notoatmodjo, S. (2010). Metodologi Penelitian Kesehatan. Jakarta: Rineka Cipta

7. Padila (2013). Asuhan Keperawatan Penyakit Dalam. Yogyakarta: Nuha Medika nya.

Bagi Peneliti Selanjutnya

Peneliti selanjutnya dapat lebih mengontrol variabel perancu untuk menghindari bias dan memberikan perlakuan konseling dengan metode yang berbeda agar kecemasan ibu primigravida dalam menghadapi persalinan dapat teratasi.

8. Kuswandi, L. (2014). Keajaiban Hypno Birthing. Jakarta: Pustaka Bunda

9. Arafah, CT, Aizar, E. (2011).Kecemasan Ibu Primigravida dalam Menghadapi Persalinan di Klinik Hj. Hadijah. Fakultas Psikologi Universitas Sumatera Utara. Skripsi

10. Novitasari.T. (2013). Efektivitas Konseling Kelompok Pra-Persalinan untuk Mengurangi Tingkat Kecemasan Primigravida Menghadapi Persalinan. Developmental and Clinical $\begin{array}{lll}\text { Psychology } 2 & \text { (2): } \quad 62-70 .\end{array}$ http://journal.unnes.ac.id/sju/index.ph p/dcp - Diakses 20 Desember 2015

11. Fajri, F. (2014). Pengaruh Konseling Terhadap Kecemasan Ibu Menjelang Persalinan di Rumah Sakit Umum Daerah Labuang Baji Makassar. Program Pasca Sarjana Universitas Hasanuddin Makassar. Thesis 